\title{
RELATIONSHIP BETWEEN PERCEPTION AND RESPONSIBILITY WITH COMMUNITY PARTICIPATION IN MANAGING COVID 19 IN CIPONDOH DISTRICT, TANGERANG CITY
}

\author{
By \\ M. I. Suhifatullah ${ }^{1}$, Widodo $^{2}$, Yunani ${ }^{3}$, Edi Mulyadi ${ }^{4}$ \\ ${ }^{1,3,4}$ Sheikh Yusuf Islamic University, Indonesia \\ ${ }^{2}$ BMKG Education and Training Center, Indonesia \\ Email: ${ }^{1}$ misuhifatullah@ unis.ac.id, ${ }^{2}$ ivanos748@gmail.com, $\underline{{ }_{2}^{2} 46 y u n i y u n a n i @ \text { gmail.com, }}$ \\ emulyadi@unis.ac.id
}

\begin{tabular}{l}
\hline \hline Article Info \\
\hline Articlehistory: \\
Received July 9, 2021 \\
Revised August 20, 2021 \\
Accepted Sept 11, 2021 \\
\\
\hline Keywords: \\
Public Perception, \\
Responsibility, Community \\
Participation, Covid 19 \\
Handling
\end{tabular}

CorrespondingAuthor:

M. I. Suhifatullah

Magister Ilmu Administrasi

Sheikh Yusuf Islamic University, Indonesia

Email: misuhifatullah@unis.ac.id

\begin{abstract}
The results to be obtained in the research are the relationship between public perception and community participation in overcoming Covid 19, the relationship between responsibility and community participation in overcoming Covid 19, as well as the relationship between perception and responsibility together with community participation in overcoming Covid 19. This research is correlational quantitative, involving 100 community members in the RW. 08 Cipondoh Village, Cipondoh District, Tangerang City, which was selected by means of Proportionate Random Sampling. Data were obtained through a calibrated questionnaire. From the research, data obtained: (1) that public perception has a positive and significant relationship with community participation in handling Covid 19 , with a value of ry. 1 $=0.731$ rtable $($ rtable $=0.195$ at $=0.05$ and rtable $=0.256$ at $=0.01)$. (2) that responsibility has a positive and significant relationship with community participation in the response to Covid 19 , with a value of ry. $1=0.661>$ rtable (rtable $=0.195$ at $=0.05$ and rtable $=0.256$ at $=0.01)$. (3) that public perception and responsibility together have a positive and significant relationship with community participation in the prevention of Covid 19 , with a value of ry. $1=0.808>$ rtable $($ rtable $=0.195$ at $=0.05$ and rtable $=0.256$ at $=0.01)$.
\end{abstract}

Thisisan open accessarticleundertheCC BY-SAlicense.

\section{INTRODUCTION}

Since the beginning of 2020 until now, people lives in various aspects (social, cultural, economic, political) have not returned to normal as a result of the Covid-19 pandemic. Worldwide based on data at https://www.google.com/search?client=firefox-b-d\&q=Number+cases+covid+19+ in+world, until March 2021 there were 126 million cases exposed to Covid-19. It was also recorded that 71.6 million were declared cured, and 2.77 million were declared dead. In Indonesia, the growth of Covid-19 cases continues to increase and is very worrying. Released data on https://www.google.com/search?q= number+cases+covid+19+di+Indonesia+day+this, the number of cases of covid 19 until March 26, 2021 has reached 1.49 million. It was also recorded that 1.32 million were declared cured and 40,166 people were declared dead. This figure is likely to continue to grow, because its growth has not been significantly controlled.

The Indonesian government, both central and regional, continues to work hard to overcome this problem, various prevention efforts through socio-cultural, economic and political approaches have been carried out, but so far have not shown encouraging results. Actually, there is a key factor that determines success in overcoming COVID- 
19 , namely the active participation of the community. The government cannot run unilaterally, because the problem of covid 19 is a common problem that must be overcome together as well.

The handling of covid 19 in Tangerang City also continues to be encouraged in earnest, this is marked by the issuance of; 1) Mayor's Circular No. 443/1097. Bag. Huk/2020 regarding the Follow-up to Prevent the Spread of Corona Virus Disease 2019 (Covid 19) in Tangerang City. 2) Mayor's Circular Number 149/1214. Bag. Pem/2020 concerning the Establishment of the Covid 19 Alert Village at the RT Level.

However, the level of community or public participation in efforts to overcome Covid 19 has not been encouraging, so the results have not been maximized. This certainly shows that the participation of the Indonesian people is still low in efforts to overcome Covid 19 , both through the $3 \mathrm{M}$ movement, namely maintaining distance, washing hands, wearing masks, and staying at home. In contrast to a number of other countries, such as Japan and Korea, which have a high level of community participation, this effort is more effective.

The various phenomena above are also found in Cipondoh Village, Cipondoh District, Tangerang City, based on the author's monitoring or observations in the community, especially in mosques in congregational prayer activities and in other community activities such as in markets and wedding venues, it was found that many violated various policies in the community. on. This is marked, among others; 1) not keeping a distance in congregational prayers, 2) not wearing a mask when outside the house, 3) jostling when shopping at the market, 4) not washing hands when entering or leaving the shop. These various social symptoms indicate that public awareness is still low in efforts to overcome Covid 19. Related to this research, the author formulates two independent variables, namely public perception and responsibility which are strongly suspected to have a relationship with community participation in handling Covid 19.

\section{RESEARCH METHOD}

The approach in this research is correlational quantitative and data collection techniques are carried out using a questionnaire. This study is related to 2 independent variables, namely public perception (X1) and responsibility (X2). The dependent variable is community participation in Covid 19 Response (Y). This study used a sample of $20 \%$ from a population of 499 , so that 99.80 or 100 respondents were assigned randomly and proportionally.

For data collection, a questionnaire for each variable was used which was arranged based on each indicator using a Likert scale, where the lowest score was 1 and the highest was $5(1,2,3,4,5)$. Before being used, the questionnaire instrument was tested on respondents outside the sample, so that the instrument had a valid and reliable value.

For data processing, the following 3 formulas were used: (1) to measure the correlation level varsial (the relationship between $\mathrm{X}$ and $\mathrm{Y}$ variables), the Product Moment (Pearson) formula was used. (2) To measure the level of contribution or contribution of variable $\mathrm{X}$ to changes that occur in variable $\mathrm{Y}$, the coefficient of determination formula (R2) is used, (3) To measure the level of correlation of the two independent variables (X1 and X2) together with the dependent variable (Y) used the F-test test formula.

\section{RESULTS AND ANALYSIS}

The results of data processing related to the $\mathrm{Y}$ variable, obtained a value of 100 as the highest score and 78 as the lowest score, 87.68 is the average score (mean), and 5.57 is the standard deviation value or standard deviation. Based on these scores, a table for calculating the frequency distribution of the $\mathrm{Y}$ variable was made, which obtained a lot of 8 grades and 3 interval distances. The $\mathrm{Y}$ variable frequency distribution table is presented as follows.

Table 1 Variable Frequency Distribution Y

\begin{tabular}{|c|c|c|c|c|}
\hline No & Kelas & Frekuensi & FrekuensiRelatif & FrekuensiKumulatif \\
\hline 1 & $78-80$ & 8 & 8 & 8 \\
\hline 2 & $81-83$ & 24 & 24 & 32 \\
\hline 3 & $84-86$ & 16 & 16 & 48 \\
\hline 4 & $87-89$ & 12 & 12 & 60 \\
\hline 5 & $90-92$ & 24 & 24 & 84 \\
\hline 6 & $93-95$ & 0 & 0 & 84 \\
\hline 7 & $96-98$ & 12 & 12 & 96 \\
\hline 8 & $99-101$ & 4 & 4 & 100 \\
\hline
\end{tabular}


International Journal of Social Science (IJSS)

Vol.1 Issue.3 October 2021, pp: 129-136

ISSN: 2798-3463 (Printed) | 2798-4079 (Online)

It is known that $24 \%$ is the highest relative frequency value associated with the $\mathrm{Y}$ variable in the range $81-$ 83 and $90-92$. It is also known that $0 \%$ is the smallest relative frequency and there is a range of $93-95$. Furthermore, the data is presented in the form of a bar graph as follows :

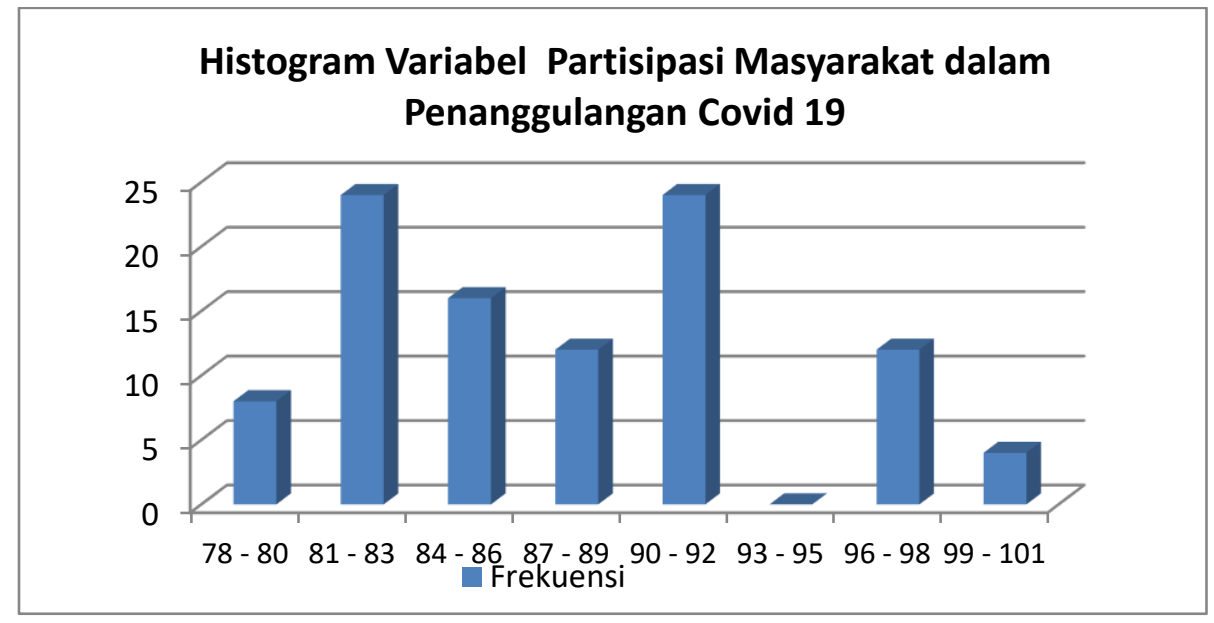

Figure 1. Histogram of the Community Participation Variables in Combating Covid 19 (Y)

Then the results of data processing related to the X1 variable, obtained the highest score of 58, the lowest score of 44, the mean or average value of 51.16. While the standard deviation value is 3.60. Based on these scores, a table for calculating the frequency distribution of the X1 variable was made, which obtained a lot of 5th grade and 3rd interval distance. The X1 variable frequency distribution table is presented below.

Table 2. Variable Frequency Distribution X1

\begin{tabular}{|c|c|c|c|c|}
\hline No & Kelas & Frekuensi & FrekuensiRelatif & FrekuensiKumulatif \\
\hline 1 & $44-46$ & 8 & 8 & 8 \\
\hline 2 & $47-49$ & 32 & 32 & 40 \\
\hline 3 & $50-52$ & 28 & 28 & 68 \\
\hline 4 & $53-55$ & 16 & 16 & 84 \\
\hline 5 & $56-58$ & 16 & 16 & 100 \\
\hline
\end{tabular}

It is known that $32 \%$ is the highest relative frequency value associated with the X1 variable in the range of 47 -49 . It is also known that $8 \%$ is the smallest relative frequency and there is a range of $44-46$. Furthermore, the data is presented in the form of a bar graph as follows:

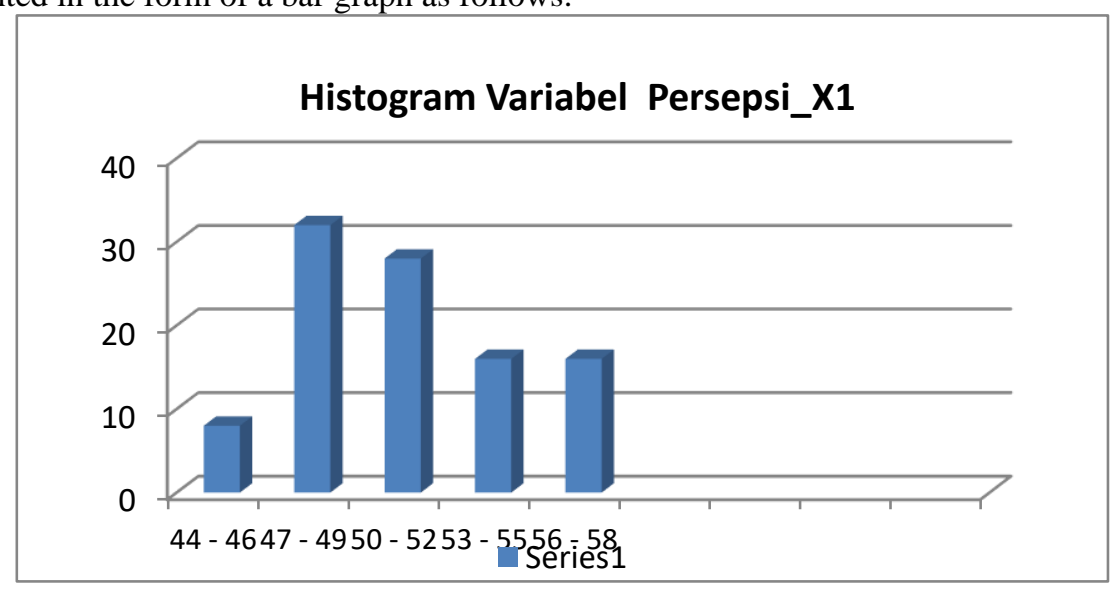

Figure 2. Histogram of Perception variable (X1) 
Furthermore, related to the X2 variable after data processing, obtained a value of 70 as the highest score, 42 as the lowest score, 62 as the mean or average score, and 5.83 as the standard deviation or standard deviation. Referring to the score value, a table for calculating the frequency distribution of the X2 variable obtained by many 8th graders and 4th interval distances is made. The $\mathrm{X} 2$ variable frequency distribution table is presented below:

Table 3. Variable Frequency Distribution X2

\begin{tabular}{|l|l|l|l|l|}
\hline No & Kelas & Frekuensi & FrekuensiRelatif & FrekuensiKumulatif \\
\hline 1 & $42-45$ & 4 & 4 & 4 \\
\hline 2 & $46-49$ & 0 & 0 & 4 \\
\hline 3 & $50-53$ & 0 & 0 & 4 \\
\hline 4 & $54-57$ & 16 & 16 & 20 \\
\hline 5 & $58-61$ & 20 & 20 & 40 \\
\hline 6 & $62-65$ & 32 & 32 & 72 \\
\hline 7 & $66-69$ & 24 & 24 & 96 \\
\hline 8 & $70-73$ & 4 & 4 & 100 \\
\hline
\end{tabular}

Referring to the data above, it can be seen that $32 \%$ of the highest relative frequency of respondents' answers related to the $\mathrm{X} 2$ variable is in the range of $62-65$. It is also known that $0 \%$ is the smallest relative frequency and there is a range of $46-49$ and a range of $50-53$. Furthermore, the data These are presented in the form of a bar graph as follows:

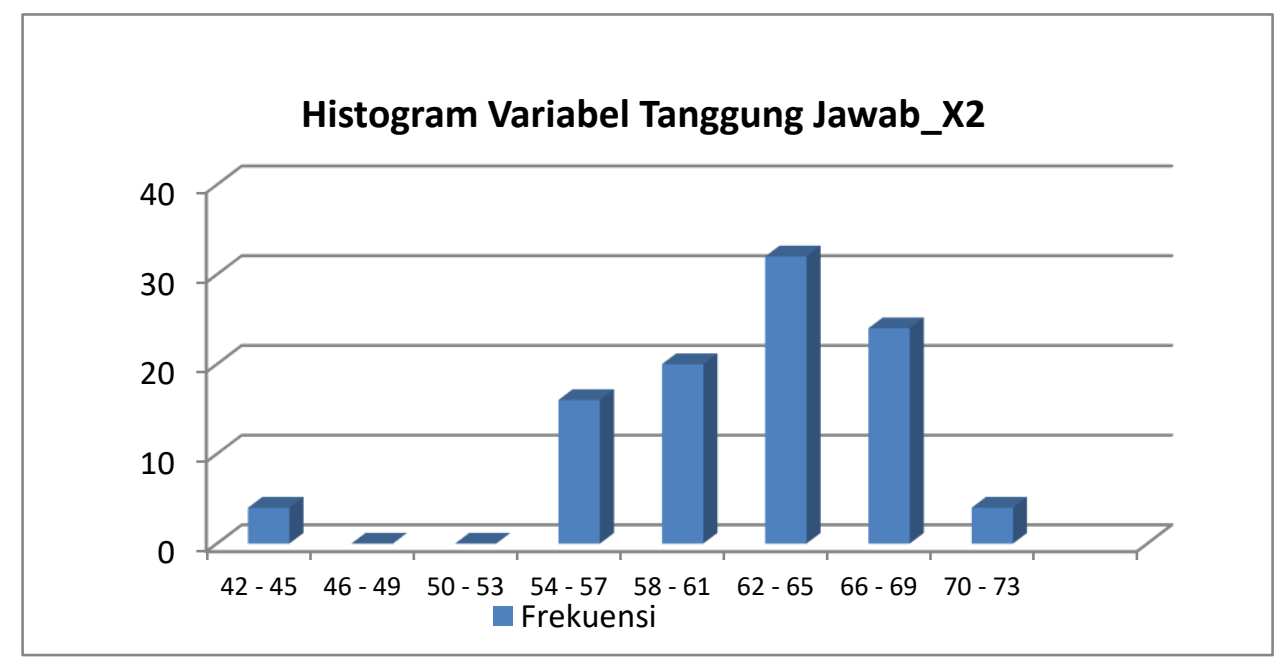

Figure 3. Histogram of responsibility variables (X2)

It is known that the data comes from a normal distribution and the population is homogeneous. This is known after testing the normality of the data and the homogeneity of the respondents or population through the SPSS 21 program. Furthermore, hypothesis testing is carried out based on the results of statistical calculations related to the level of correlation of variable $\mathrm{X}$ with variable $\mathrm{Y}$ both based on each $\mathrm{X}$ variable or simultaneously, the following results are below this :

1. That the results of calculations related to the perception of their relationship with community participation in handling Covid 19 show the value of ry. $1=0.731$ which is greater than rtable $=0.195$ at $=0.05$ and rtable $=$ 0.256 at $=0.01$. This finding is also confirmed by the calculation of the value of $\mathrm{r} 2=(\mathrm{ry} .1) 2=0.534$, which means that $\mathrm{X} 1$ contributes $53.40 \%$ to the changes that occur in the $\mathrm{Y}$ variable. Then based on the calculation of the regression analysis, the value of $=29.846+1.130 \mathrm{X} 1$ is obtained. Through the significant test of the regression equation, the data obtained by Fcount $=112.176$ is greater than Ftable $=3.09$ at $=0.05$ and Ftable $=$ 4.82 at $=0.01$. The data means that the $\mathrm{X} 1$ variable has a functional relationship with the $\mathrm{Y}$ variable. On that basis $\mathrm{H} 0$ is rejected and $\mathrm{H} 1$ is accepted, due to the fact that perception (X1) has a very strong positive relationship with community participation in handling Covid 19 (Y).

2. That statistical calculations related to the relationship between responsibility and community participation in handling Covid 19, obtained a value of ry. $1=0.661$, which is greater than rtable $=0.195$ at $=0.05$ and rtable $=$ 0.256 at $=0.01$. This finding is also confirmed by the calculation of $\mathrm{r} 2=(\mathrm{ry} .1) 2=0.437$, which means that the 
International Journal of Social Science (IJSS)
Vol.1 Issue.3 October 2021, pp: 129-136
ISSN: 2798-3463 (Printed) | 2798-4079 (Online)

DOI: https://doi.org/10.53625/ijss.v1i3.404

$\mathrm{X} 2$ variable contributes $43.70 \%$ to the changes that occur in the $\mathrm{Y}$ variable. Then based on the calculation of the regression analysis, the value of $=48.526+0.632 \mathrm{X} 1$ is obtained. Through the significant test of the regression equation, the data obtained by Fcount $=76.209$ is greater than Ftable $=3.09$ at $=0.05$ and Ftable $=4.82$ at $=0.01$. The data means that the $\mathrm{X} 2$ variable has a functional relationship with the $\mathrm{Y}$ variable. On that basis $\mathrm{H} 0$ is rejected and $\mathrm{H} 1$ is accepted, due to the fact that responsibility (X2) has a very strong positive relationship with community participation in handling Covid 19 (Y)

3. That statistical calculations related to the relationship between perception and responsibility with community participation in the prevention of Covid $19(\mathrm{Y})$ obtained a value of ry. $1=0.808$, which is greater than rtable $=$ 0.195 at $=0.05$ and rtable $=0.256$ at $=0,01$. This finding is corroborated by the value of $\mathrm{r} 2=(\mathrm{ry} .1) 2=0.645$, which means that there is a contribution from the perception and responsibility variable to community participation in the COVID-19 response of $64.50 \%$. Then based on the calculation of the regression analysis, the value of $=21.916+0.826 \mathrm{X} 1+0.379 \mathrm{X} 2$. Through the significant test of the regression equation, the data obtained Fcount $=91.104>$ Ftable $($ Ftable $=3.09$ at $=0.05$ and Ftable $=4.82$ at $=0.01)$. On that basis, H0 is rejected and $\mathrm{H} 1$ is accepted, due to the fact that perception (X1) and responsibility (X2) together have a very strong positive relationship with community participation in overcoming Covid 19 (Y)

It can be explained that perception is a person's understanding or knowledge in looking at something based on information and experience obtained from the environment. This is as stated by Desiderato in Rakhmat (2014: 51), namely: "The essence of perception is an individual's experience of events or objects that have been observed or various relationships by inferring information and providing interpretations." Mar'at (2012: 23) also stated that, "perception can be interpreted as the result of someone's observation centered on his cognition system. In addition, perception is also influenced by factors of insight, experience, and the learning process". So differences in perception can occur, because in addition to different sensory experiences, the factors that influence them are also different.

The public's perception or understanding of a program designed and implemented by the government, of course has a relationship with the level of participation given by the community to the program or in this study community participation in overcoming Covid 19 . The more positive the public's perception or view of efforts to overcome the Covid 19 problem, the level of community involvement or participation in activities to overcome Covid 19 will also be high.

Based on the explanation above, both theoretically and empirically it can be concluded that public perception has a strong relationship with the level of community participation in overcoming Covid 19. Therefore, if there is a phenomenon of low community participation in Covid 19 prevention activities, it is necessary to make efforts to improve public perception of the problem of Covid 19.

Responsibility is a human behavior or action that is realized or not realized but must be willing to bear the risk or the consequences in front of other people or God. Related to this, Mustari (2017: 21) explains that "responsibility is an individual's attitude and behavior in carrying out the duties that are his obligations seriously, such as towards oneself and other environments including God".

The results of the study indicate that responsibility makes a significant contribution to changes that occur in community participation in overcoming Covid 19. This means that the higher a person's responsibility in a community activity, the greater the impact on participation in overcoming Covid 19. Hawari (2015: 199) revealed that "responsibility is an individual's attitude and behavior that is the basis for responding to various situations and conditions every day, this is related to various aspects of behavior based on the highest morals",

In everyday life, both in personal and social contexts, responsible attitudes and actions are very important as characteristics of a moral personality. Therefore, the behavior of people who ignore their responsibilities by taking actions that are detrimental to themselves and the environment is tantamount to immoral people.

From the analysis above, it can be concluded that responsible individuals will always do the best activities that are beneficial for their personal lives as well as for society. This also makes a person have the initiative and be proactive to participate in various activities in the community.

Based on the explanation above, both theoretically and empirically, it can be concluded that responsibility has a strong relationship with the level of community participation in overcoming Covid 19. Therefore, if there is a phenomenon of low community participation in overcoming Covid 19, then there needs to be efforts to foster responsibility responsible for society. With these efforts, it is hoped that it will increase community participation in the fight against Covid 19

Community participation in government programs in the context of community development is a social behavior without expecting remuneration. The social behavior is purely because they feel called to participate or take part in a joint activity in the community. This is as expressed by Huneryear and Heoman in Dwiningrum (2015: 32) revealing, that "participation is essentially a physical and mental involvement in group activities, so that the initiative 
to contribute something that is owned or that can be held together is responsible for realizing a common goal." .Pidarta (2016: 340) also says: "Participation is the participation of a person or group of people in an activity by involving physical and mental activity and contributing with all the abilities they have as a sense of responsibility to support the achievement of group goals".

So participation is a person's mental calling to act socially or selflessly. This means demanding a strong and correct understanding of the program that is the object of participation. In addition, mental or moral responsibility is also needed to be willing to take social actions or participate in overcoming Covid 19.

Based on the explanation above, both theoretically and empirically, it can be concluded that perceptions and responsibilities have a strong relationship with the level of community participation in overcoming Covid 19 . Therefore, if there is a phenomenon of low community participation in overcoming Covid 19, then there needs to be socialization efforts. intensive programs as well as fostering the attitude of community responsibility towards joint activities.

\section{CONCLUSION}

Conclusions from the exposure or study above include, namely:

1. It is proven that perception has a positive and significant relationship with community participation in handling Covid 19 in Cipondoh Village, Cipondoh District, Tangerang City. These findings have implications for the need for more intensive socialization related to the handling of Covid 19.

2. It is proven that responsibility has a positive and significant relationship with community participation in handling Covid 19 in Cipondoh Village, Cipondoh District, Tangerang City. These findings have implications for the importance of fostering the community regarding awareness of the nation and society so as to increase their social responsibility.

3. It is also proven that perception and responsibility simultaneously have a positive and significant relationship with community participation in handling Covid 19 in Cipondoh Village, Cipondoh District, Tangerang City. These findings have implications for the importance of more intensive COVID-19 socialization and community responsibility development.

\section{Recommendation}

Based on these conclusions, recommendations are made, including:

1. For the Cipondoh Village, Cipondoh District, Tangerang City

a. There needs to be an intensive and rational effort to socialize the prevention of Covid 19 to the community to improve and straighten people's understanding of Covid 19. Through these efforts, it is hoped that it can have an impact on increasing community participation in handling Covid 19.

b. There needs to be efforts to foster an attitude of responsibility towards the community, including through the state defense program. Through these efforts, it is hoped that it will have an impact on increasing community participation in dealing with COVID-19.

2. For the people of Cipondoh Village, Cipondoh District, Tangerang City

a. The public needs to make efforts to improve their perception of the Covid 19 problem, both through responsible mass media and through participation in the socialization of the Covid 19 problem. Through these efforts, it is hoped that this will have an impact on increasing community participation in handling Covid 19.

b. The community needs to try to improve their moral responsibilities, among others, by participating in the state defense development program. Through these efforts, it is hoped that it will have an impact on increasing community participation in dealing with Covid 19

\section{REFERENCES}

[1] Dwiningrum, Siti Irene Astuti. 2015. Decentralization and Community Participation in Education. Yogyakarta: PustakaPelajar

[2] Harihanto. 2011. People's Perceptions, Attitudes, and Behaviors towards River Water, Dissertation, Postgraduate Program, Bogor Agricultural University

[3] Hawari, Akka. 2012, Teacher with Strong Character, Jogjakarta :Laksana

[4] Good luck, Inu. 2016. State Administration System of the Republic of Indonesia. Bandung: PT BumiAksara.

[5] Mar'at. 2012. Human Attitude: Change and Its Measurement. Bandung: Ghalia Indonesia.

[6] Mustari, Mohamad. 2014. The Value of Character Reflection for Character Education. Yogyakarta: LaksbangPressindo

[7] Ndraha, Taliziduhu. 2015. Participation in Development .Jakarta : LP3ES 
International Journal of Social Science (IJSS)

Vol.1 Issue.3 October 2021, pp: 129-136

ISSN: 2798-3463 (Printed) | 2798-4079 (Online)

crossref DOI: https://doi.org/10.53625/ijss.v1i3.404

[8] Pidarta, Made. 2016. Indonesian Education Management. Jakarta: RinekaCipta.

[9] J Grace, Jalaluddin. 2014. Communication psychology, Bandung: Rosdakarya Youth

[10] Sumarto. 2016. Innovation, Participation and Good Governance. Jakarta: Torch Foundation

[11] Suryadi, A. 2016. Village Community Development, PT. Alumni, Bandung

[12] Thoha, Miftah. 2015. Leadership in Management. Jakarta: PT. King GrafindoPersada.

[13] WalgitoBimo. 2017. Social Psychology, Yogyakarta, Andi

[14] Web Source:

https://www.google.com/search?client=firefox-b-d\&q=Jumlah+kasus+covid+19+di+dunia,

https://www.google.com/search?q=jumlah+kasus+covid+19+di+indonesia+hari+ini 
